\title{
国
}

ISSN 2278 - 0211 (Online)

\section{Rural Economies and Human Development: The Case of Nkayi District, Zimbabwe}

\author{
Whitehead Zikhali \\ Senior Lecturer, Institute of Development Studies (NUST-IDS), \\ National University of Science and Technology, Bulawayo, Zimbabwe
}

\begin{abstract}
:
Although development theory has provided numerous insights into what development means, the ideological contrasts between theories have meant that solutions have swung from one extreme to another. This has been resolved in part through Amartya Sen's conception of 'development as freedom' which places humans at the centre of development. Starting from this premise, the paper considers the various economies which people in Nkayi District - an area in rural Zimbabwe- resort to fashion their version of development. Economies are not construed in strictly economic terms but span across socio-economic boundaries. The paper reveals that although residents rely on diverse economies, contribution of livelihood components is varied and inconsistent across farming (45\%), labour (24\%), mining (12\%), assets (13\%), pensions (4\%) and loans (2\%). The shallow spread calls for more inclusive policies as well as a rethink on how best to ensure that rural areas achieve broadbased, inclusive development.
\end{abstract}

Keywords: Development, development theory, livelihoods, economies, capabilities, Zimbabwe

\section{Introduction}

Development theory has mutated over time all to explain the realities of various people in the developing world. Such realities have been discussed through dependency theories, world systems theories, modernization among others. Also used in consistency with the theoretical frames have been notions of localised development which in the main have been influenced by research in select parts of the globe. In this bracket lie such approaches as the sustainable livelihoods framework and more recently, conservation agriculture. What emerges from the various perspectives proffered is a litany of solutions which have mainly proven unsuccessful for many reasons. This paper is embedded within this broad history of development thinking. It observes the broad theoretical perspectives but does not necessarily find a perfect home in any of them. Instead, it resonates more with the nuanced approach of social anthropologists whose term, glocal, captures the globally influenced, localised forms of change. Such an approach would mean that concepts of development as a purely economic endeavour are inadequate. While economics is indeed important, metrics such as GDP/ capita or income alone are insufficient in capturing people's aspirations. It is for this reason that the paper deploys the term economies not in an economics sense but to depict various modes of production which people rely upon for their livelihoods. Such modes include social networks, labour resources and financial resources.

The paper discusses local development in Nkayi, a district in Zimbabwe comprised of largely rural households. It observes various livelihood portfolios which inhabitants of the district possess and what such portfolios mean for human development. The question then is, 'why conduct such a study? In addition, why Nkayi?' to start off, Zimbabwe has endured a very dark economic and political period since the year 2000 which has been exacerbated by intermittent droughts. As a result, rampant unemployment, hunger and disease have swept over many sections of the population. Yet, the population has proved resilient in the times of difficulty. While numerous fields have considered the strategies which citizens have employed to survive, to the best of the author's knowledge, there is no consolidated piece of work, which encapsulates all experiences into a uniform narrative.

The research was conducted in Nkayi for two main reasons. The first reason is that Nkayi comprise of people who have traditionally comprised part of the migrant stream to destinations such as Bulawayo, a major city in Zimbabwe and South Africa, the country's neighbour to the south. This means that agro-based livelihoods are not the only source of income for local communities. The second reason is that poverty levels in Matabeleland North -in which Nkayi is situated- remain high even by national standards with poor showings in child welfare indicators, dependency ratios as well as high dependence on food support (ZimVac, 2016). The paper is laid out as follows: the section after the introduction is a brief literature review of 
development theory as well as notions of human development. After the literature review, a methodology section is outlined together with a description of the study site. Presentation of findings follows, and it too is succeeded by discussion and analysis. Conclusions and recommendations from the last section of the paper.

\subsection{Human Development, Livelihoods and Growth: A Review of the Literature}

Amartya Sen's seminal work on human development has proven useful in revealing the disjuncture between development as construed in broad economic terms and human development which places people at the heart of the development agenda. It clarified the dearth in 'use value' - to borrow from Marx- of economic goals such as economic growth. In other words, growth for growth's sake was of little import to humanity if it did not benefit people. Sen (1999) identifies development as constituting an attainment of 'freedoms' whose realization equally depends on capabilities. The utility of this perspective is that it shies away from largely economics-rooted conceptions of development. Hence, it is not about attainment of Gross Domestic Product, Gross National Product, macroeconomic stability or bridging dual economic structures but simply about people. In placing people at the centre of development Sen (1999) does not dismiss the economic goals. Instead, he points to what these goals should really be attuned towards.

The focus on human development was not always obvious. Instead, over time, numerous worldviews have dominated development with typically Marxist theories such as regulation, dependency and world systems theories contrasting with modernization and globalization among others (Peet \& Hartwick, 2009). The ideological contrast has resulted in divergent prescriptions as one set of theories demands a shift in structure (Marxist theories) while the opposing camp places emphasis on a free market system delivering 'development' through trickle-down effects. Among the theories on bridging the divide between rural backwardness (a traditional sector) and an urban sector has been Sir Arthur Lewis' dual economy thesis which centres of labour transfers and urban employment growth (Todaro, 1982). This theory is in stark contrast with Marxist thinkers who in their most modest submissions advocated for structural change and in their most extreme demanded revolution. Unlike Lewis and other modernists, development could not be left to 'processes' but required active change. This is a theme which emerges in our discussion.

In recent times, development thinkers have refrained from taking the extreme positions of the past albeit without moving out of their ideological schools. Hence in the adherents of the market economy and modernization, some have recognised the shortcomings of dogmatic approaches. Among these have been writers such as Joseph Stiglitz in his 'Globalization and its Discontents' as well as other post-modernists. These shifts together with the Brundtland Commission's 'Our Common Future' report (Brundtland Commission, 1987) as well as prominence of ideals such universal rights frameworks have contributed to more humanist approaches.

In the same vein as Sen's earlier stated 'development as freedom' treatise, scholars such as Chambers \& Conway (1992) have considered the livelihoods of people in the developing world. Their income-centred approach reveals that there are numerous ways in which people can achieve meaningful livelihoods and avert poverty over times characterised by interspersed strain. This livelihoods approach identifies various forms of capital (human, financial, natural, physical and social) and how people can deploy these to attain decent livelihoods. Identifying the forms of capital is not an end but proves useful particularly where households experience 'shocks' and then resort to either one, a mix or all of the capitals to mitigate the effects (Ellis \& Freeman, 2005). The sustainable livelihoods approach fits excellently in contexts across many parts of the developing world such as Africa and Latin-America. Alternative approaches which have been devised elsewhere include the Community-Business Matching Model which assists in identifying desirable industry sectors for sustainable economic development (Buescher, Halbrendt, \& Sullivan, 1999). This approach hinges on finding desirability and compatibility of factors for development to be achieved. It is useful to note that it captures the buzzword of the past two decades in 'sustainable development' which has been a catchphrase in a rapidly globalized world.

Lastly, the changes in development thinking have transpired through influences of various fields of expertise and cultures. After Arjun Appadurai's conception of the global village complete with ethnos capes, technoscapes, ideas capes, finans capes and medias capes (Appadurai, 1990), a more localised globalist perspective has emerged. This approach which conceives of development from the grassroots gives agency to actors who have previously been recipients of 'solutions' from elite technocrats in the global north. Its manifestation is evident in

\subsection{Human Development in Zimbabwe}

In Zimbabwe, the focus on rural development has tended to adopt various policies which mirrored the dominant policy positions and ideological convictions of the time. Hence, in the 1980s, the growth-point approach which sought to enable rural areas to catch-up with urban centres was dominant (Wekwete, 1988). With the advent of ESAP, the approach's popularity appeared to wane although the challenges which it has imposed on various layers of rural governance did not ebb with it. For example, Hammar (2008) recognizes a complex web of political formations each with allegiances of its own and implications for who governs. Her study reveals that in Gokwe North in the late 1990s there existed a strained relationship between the RDC and segments of the rural communities of both earlier settlers and later migrants, resulting in contradictory and sometimes competing positions of the RDC and traditional leadership of the area. While the traditional leadership had allocated land to the 'new' migrants thereby making them legitimate residents within a customary law framework, the RDC considered the migrants to be 'squatters' because they mostly did not have 'letters of removal'. These letters were documents issued by councils through which they asserted their authority to grant rights of habitation to new settlers in each locality. 
Consequently, a governance crisis prevailed in the area with a lack of transparency, clarity and accountability over the land matter. Apart from the governance conundrums, rural development has tended to be entwined with agricultural policies and reforms, a clear enduring effect of colonial development policies. Such approaches as conservation in general (Wilson, 1995; Mandondo, 2000; Gumbo, Snelder, Wuta, \& Nyagumbo, 2012) and conservation agriculture (Marongwe, et al., 2011; Baudron, et al., 2012; Nkayi RDC, 2014).

The development policies have tended to be concerned with economic progress as detailed in the specific economic policies ranging from Transitional National Development Plan, Economic Structural Adjustment Program (ESAP) to the National Economic Recoery Plan (NERP). The current policy dubbed the Zimbabwe Agenda for Socio-Economic Transformation appears to be assume a slightly different tenor as it embraces social change in addition to ecnomic progress. However, it remains largely tilted towards economics. With the skewed focus on economics, social and what Sen would identtify as human development' issues have suffered particularly in the period between 2000 and 2009 when unprecedented hyperinflation ravaged through virtualy every sphere of life. This is evident as Zimbabwe was classified as a middle income country in 1990 but had become worse off in 2010 than it was in 1970 with a Human Development Index of 0.14 (UNDP, 2010). The general response in this time of implosion was to either migrate (Crush \& Tevera, 2010; Tevera \& Crush, 2010) or resort to a mix of largely informal income-generating activities which at times bordered on illicit (Jones, 2010). In rural areas, these activities became so nuanced that although they were situated in rural settings, they resorted to networked which had transnational reach. This is evident in the mining sectors where diamond smugglers (Nyamunda \& Mukwambo, 2012) and gold dealers (Mabhena, 2012) networked with artesanal miners. Such transnational reach co-existed with local livelihods forms which involved agriculture on plots of land as well as traditional methods such as bee-brewing. The studies which have identified these elements of livelihoods formation are in the main disparate and give the imression that households resorted to the livelihoods as unrelated entities. It is the recognition of livelihoods as a portfolio which allows this paper to reveal the interrelatedness of livelihoods. We return to this matter in the discussion. Importantly, the artesanal miners as well as informal sector workers have won recognition from the governemnt such that their concerns are often accommodated in regulations and policy (for example Statutory Instrument 64/2016). Such recognition has allowed for a proliferation of economic activity in both urban and rural settings.

\section{Methodology}

The study employed a mixed methods approach on a sample of households strewn across Nkayi district. A multi-stage sampling framework was employed in the following sequence:

- From the 30 wards in Nkayi District, a systematic random sample was chosen using a threshold of $20 \%$ of the population. This translated to 6 wards being selected namely wards 2, 5, 7,15,20,27.

- The second stage comprised purposively selecting one village within each ward and this resulted in six villages selected.

- The third stage in the sampling approach entailed purposively selecting households within the sample. A purposive selection was employed for the main reason that gaining consent in Zimbabwe is seldom a given. Therefore, relying on households known through previous research encounters as well as familiar with research processes through associations with NGOs was likely to yield consent and active participation. To put this matter into context, there is often suspicion -on the part of participants in rural communities- of the motives of research. This suspicion was particularly heightened during the final leg of the study when Zimbabwe experienced an unconventional political transition in November 2017 after the ouster of Robert Mugabe. Without sufficient social capital in such settings, gathering data using for example random samples would have been a daunting task indeed. Three households per village were selected giving the sample size a total of eighteen households $(n=18)$. In each household, the oldest person, median and an adolescent were selected for interviews. This meant that a total of three possible interviewees could be identified in a household. However, where there was potential for duplication (for example where an adolescent was also able to be the median), only two interviews were conducted. The total participants therefore were forty-two $(n=42)$

\subsection{A Description of the Study Site}

Nkayi is a district in Matabeleland North Province of Zimbabwe. It is characterised by low rainfall, poor infrastructure and semi-arid to arid conditions. Rainfall tends to be very low in the area with mean amounts of between 17-70 mm (Hoko, 2005). As already noted above, it is administratively divided into 30 wards which in turn have been subdivided into 156 villages (NkayiRDC). The wards include those sampled in the study as depicted in Table 1 below. 


\begin{tabular}{|c|c|}
\hline Ward & Ward Name \\
\hline 2 & Mapasapasa \\
\hline 5 & Nesigwe \\
\hline 7 & Gwamayaya \\
\hline 15 & Skopo \\
\hline 20 & Zinyangeni \\
\hline 27 & Mjena \\
\hline
\end{tabular}

Table 1: Sampled Nkayi Wards

The 2012 population census notes that Nkayi's population totalled to a figure of 109, 371 people with an average household size of 5.1 persons (ZimStat, 2011). The distribution is almost a prefect split by gender. However, much like Zimbabwe's general population, the age structure is largely reflective of a youthful population which unfortunately has the unenviable position of being largely unemployed. As a result, it is hardly surprising that dependency ratios in Nkayi are high in line with the provincial statistics, with the youngest often suffering from difficult circumstances (ZimVac, 2016). Figure 1 below reflects this hardship in light of stunting among children with Nkayi faring as the third worst district in Zimbabwe at 40\% prevalence (ZimVac, 2016, p.137).

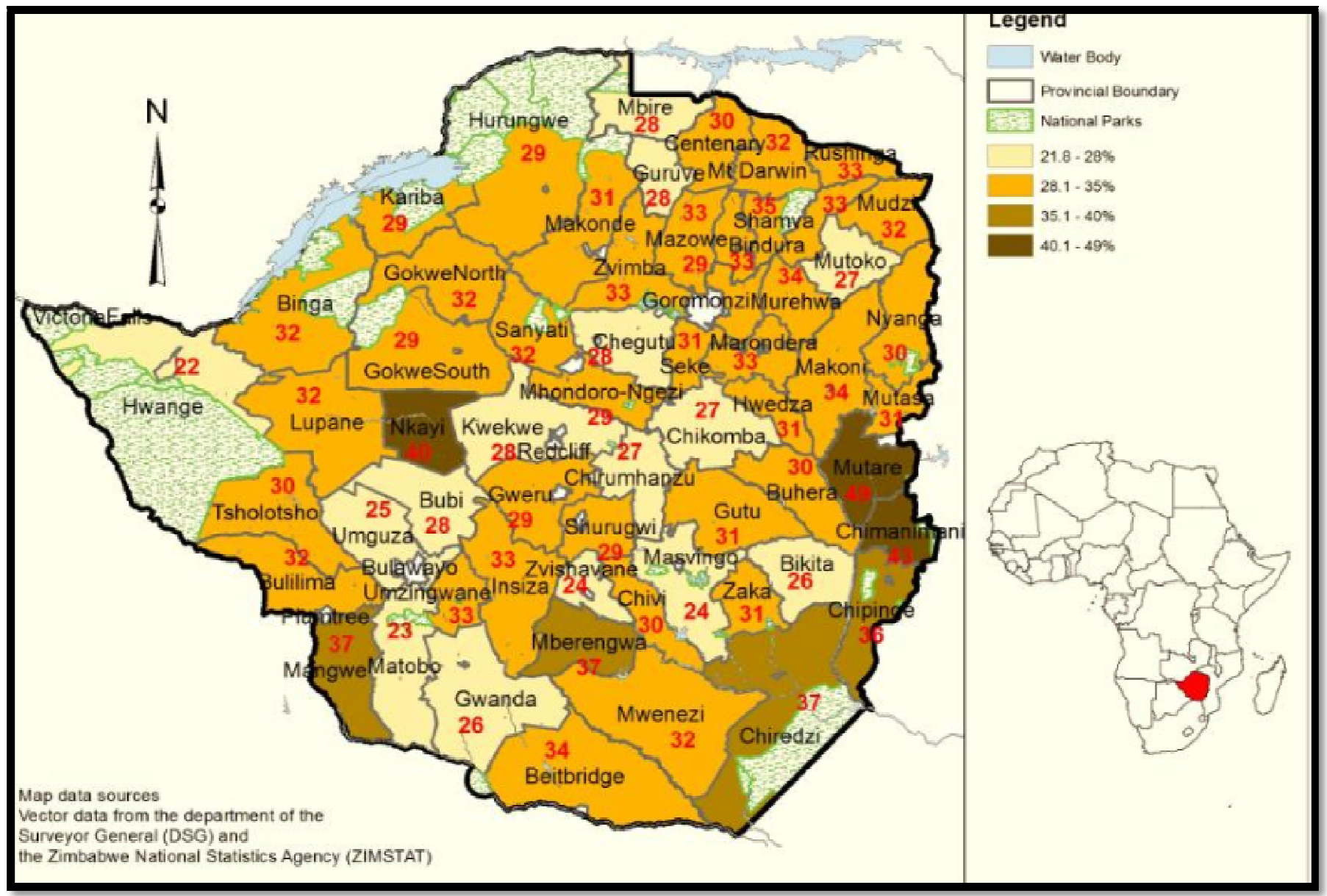

Figure 1: Prevalence of Stunting by District

Source: Zim Vac (2016, p.137)

\subsection{Findings}

The findings presented here are divided on the grounds of form and theme. By form, is meant the type of data which was identified, that is, whether such data was qualitative or quantitative. Thematic separation hinged on the broad themes which the data revealed. But first a description of the sample is provided in the graphic below.

\begin{tabular}{|c|c|}
\hline Age & 27.5 (Average) \\
\hline Gender & Male 19 (45\%); Female 23 (55\%) \\
\hline
\end{tabular}

Table 2: Description of Population Sample 
The distribution of the population by age and gender is as depicted in Table 2 above. The average age is a bit misleading because many families were headed by young people and those that were not tended to have a person above the age of 60 and adolescents. Young adults were either absent or had migrated to local towns and destinations outside of Zimbabwe. The data collected was both qualitative and quantitative. A breakdown of the quantitative data follows below. For now, a description of the qualitative data which touched on participants' notions of development and their aspirations. There were 15 adolescents in the sample group and they were asked to identify signs of development as well as what they wanted to be in life. The first part sought to establish how they conceived of development, that is, whether they placed themselves in the process of development or whether they identified it as a provision of such items as infrastructure and institutions. The second part addressed their aspirations and therefore their human development hopes. Of the 27 adults in the sample, similar questions were asked with the second being modified slightly and identifying whether the adults had indeed achieved what they sought to. As a result, the data presented in Table 3 below shows responses for both adolescents and adults to the first questions.

\begin{tabular}{|c|c|}
\hline \multicolumn{2}{|c|}{ Defining Development } \\
\hline Infrastructure & $52 \%$ \\
\hline Empowerment & $60 \%$ \\
\hline National Success & $93 \%$ \\
\hline
\end{tabular}

Table 3: Responses to Questions on How Participants

Defined Development $(\mathrm{N}=42)$

Data in table 3 above has been arranged to fit into three common themes which participants identified. The specific responses tended to vary, for example with people identifying roads, clinics, schools and boreholes as forms of development. These would all be grouped under infrastructure. Having identified the general perceptions of development, disaggregated responses for the two groups was assessed for the second part and is presented in Table 4 and Table 5 below.

\begin{tabular}{|c|c|}
\hline \multicolumn{2}{|c|}{ What are Your Aspirations } \\
\hline Get a job & $40 \%$ \\
\hline Own business & $13 \%$ \\
\hline Leave area for urban centre & $80 \%$ \\
\hline
\end{tabular}

Table 4: Adolescent Aspirations for Personal Development ( $\mathrm{n}=15)$

Again, the data was more nuanced than presented in Table 4 above. The adolescents identified specific occupations which they wished to attain (such as nursing, teaching and driving public transport vehicles) but these have been placed under the banner of getting a job.

\begin{tabular}{|c|c|}
\hline \multicolumn{2}{|c|}{ Have You Attained What You Aspired for } \\
\hline & Yes \\
\hline Businessperson & $81 \%$ \\
\hline Own modern house & $41 \%$ \\
\hline Assets & $52 \%$ \\
\hline Family & $7 \%$ \\
\hline
\end{tabular}

Table 5: Adult Sample Assessment of Their Development $(n=27)$

Table 6 shows the livelihood options available to 34 participants who served as household heads. The number includes the 27 adults plus seven adolescents who had to work to fend for their siblings. 


\section{Human Capital}

\begin{tabular}{|c|c|c|}
\hline \multicolumn{3}{|c|}{ Human Capital } \\
\hline Highest Attainment & & \\
\hline Years in School & 11 Yrs Ave; Highest & tandard Deviation $=2.3$ \\
\hline Formal training & No $=85 \%$ & Yes $=19 \%$ \\
\hline \multicolumn{3}{|c|}{ Financial Capital } \\
\hline Bank & Yes $=18 \%$ & No $=82 \%$ \\
\hline Investments & Yes $=0 \%$ & $\mathrm{No}=100 \%$ \\
\hline Pension & Yes $=9 \%$ & No $=81 \%$ \\
\hline Remittances & Yes $=68 \%$ & No $=32 \%$ \\
\hline \multicolumn{3}{|c|}{ Physical Capital } \\
\hline Assets & Yes $=100 \%$ & No $=0 \%$ \\
\hline Livestock & Yes $=94 \%$ & No $=6 \%$ \\
\hline \multicolumn{3}{|c|}{ Natural Capital } \\
\hline Land & Yes $=94 \%$ & No $=6 \%$ \\
\hline Mine permit & Yes $=0 \%$ & No $=100 \%$ \\
\hline \multicolumn{3}{|c|}{ Social Capital } \\
\hline Social Groups & Yes $=79 \%$ & No $=21 \%$ \\
\hline Family & Yes $=91 \%$ & No $=9 \%$ \\
\hline
\end{tabular}

Table 6: Livelihoods Options Available in Lupane (n=34)

The last set of questions sought to establish the diversification of livelihoods above in two aspects namely (1) contribution to household incomes and, (2) utility to household. Table 7 below reveals the description of income data after processing in IBM SPSS v.19.

\begin{tabular}{|c|c|c|c|c|c|}
\hline & $\mathbf{N}$ & Minimum & Maximum & Mean & Std. Deviation \\
\hline Mining & 34 & 0 & 150 & 15.29 & 36.947 \\
\hline Farming & 34 & .00 & 100.00 & 55.8824 & 26.18323 \\
\hline Pensions & 34 & .00 & 70.00 & 5.0000 & 16.56027 \\
\hline Loans & 34 & .00 & 20.00 & 2.6471 & 6.65552 \\
\hline Assets & 34 & .00 & 100.00 & 15.5882 & 22.45415 \\
\hline Labour & 34 & 10.00 & 60.00 & 30.5882 & 12.77810 \\
\hline $\begin{array}{c}\text { Valid N } \\
\text { (listwise) }\end{array}$ & 34 & & & & \\
\hline
\end{tabular}

Figure 7: Descriptive Statistics of Household Income Contributions

From the data in Table 7, a distribution of incomes was computed and is presented in Figure 2 below.

\section{Distribution of income by livelihood} options

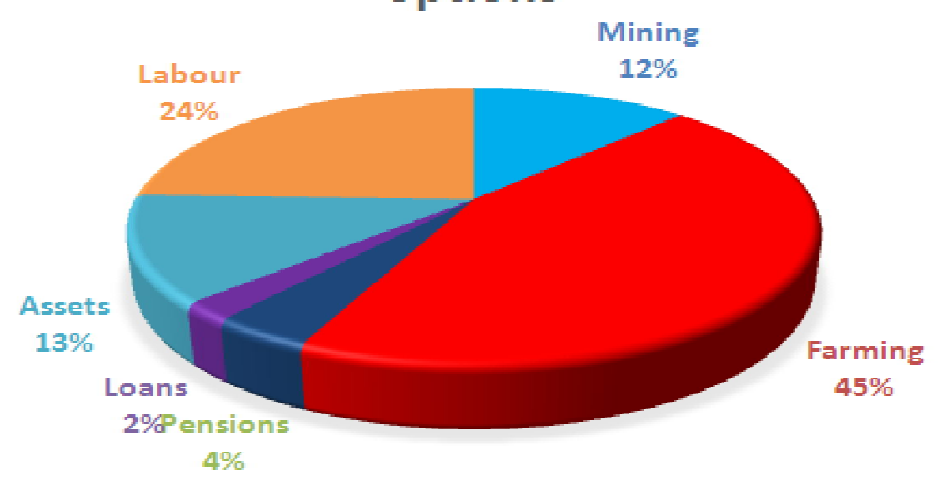

Figure 2: Distribution of Monthly Income 
The distribution of monthly income shows the average general composition of monthly incomes cross households. To gain a grasp of the real spread by sector, refer to the appendices. A discussion alluding to this matter follows in the section below.

\section{Discussion}

Before delving into a thematically informed discussion of the findings presented above, recognition of the fact that wards in the district differ in size. More importantly, the district centre is in ward 29 -which did not constitute part of the sample- hence the limited diversity of livelihoods into non-primary activity sectors such as household enterprises.

In the context of the study, it is evident that there is a diverse set of livelihood incomes which the sample has composed into a portfolio. The key activities which contribute to incomes of participants are mining, farming, renting out of assets, labour income, loans from networks as well as pensions. These are not necessarily resorted to by every household in the sample. As the appendices section reveals, distribution varies by households leading to levels of engagement. For example, $82 \%$ of households do not participate in mining while the remaining $18 \%$ is generously distributed and tends to contribute varying amounts to the households involved. Equally important to note is that while there are households which claim to receive incomes from mining, none of the participants had the paperwork needed to engage in mining. This is compounded by the fact that none of the participants was employed at a mine either. Evidently, miners are engaged in artisanal mining which poses risks to the miners and exposes their families to income shocks. Associated with the mining sector-driven income is the matter of labour. While mining and farming were deployed as indicators for natural capital, labour spent was an indicator of human capital. The contribution of natural capital to a household's livelihood is most extensive as depicted by the $57 \%$ (mining and farming) share in Figure 2 above.

Labour capital comprises of a diverse set of activities which include but are not limited to odd jobs such as repair work, hiring out labour on other people's plots, running errands on behalf of other people as well as activities such as commercial sex work. Such diversity mirrors observations made in other studies such as in Tanzania (Bryceson, Jønsson, \& Verbrugge, 2013). Indeed, due to the social stigma that commercial sex work carries, the very few participants who engage in this activity indicated that they often relocated to ply their trade, often going to places where artisanal mining was conducted. Labour contributes the second highest proportion of income in general within households despite household members mostly comprising of persons with little or limited academic achievement and low formal skill. A clear shortcoming in creating an enabling environment for expanding people's capabilities exists and this has implications for their development not just in income terms but generating agency and wellbeing. The third highest are assets which were items of value which could be used to generate direct income or contribute to a household's material needs. Carts, wheelbarrows, peanut butter machines and bicycles constituted some of the items in this category. In many cases, the use of these assets was fruitful for households because assets were rented out to other households which in turn paid a small fee. A donkey-drawn cart for instance could be rented out to a household which wanted to draw water from far off, to collect unwieldy goods or ferry an ailing family member to a distant clinic. Importantly, half of the households had no assets to speak of while those which had derived paltry incomes anyway. This suggests that although assets may be positioned reasonably well in the portfolio as reflected in Figure 2, they how ever are quite insignificant for many families. Within a livelihoods framework, this makes them largely insignificant.

Presumably due to the low levels of financial inclusion of persons in rural areas across Southern Africa (Genesis Analytics, 2003) or the generally poor economic situation, financial capital plays a paltry role in the portfolio. Despite $68 \%$ of households receiving remittances and $18 \%$ with savings accounts in banks, it was evident that financial assets played a miniscule role in the portfolio. Two comments can be made from these observations. The first is that participants in the study may have been representative of the general financially excluded population which often typifies lowly integrated communities. The second is that incomes may quite invariably be of little import in this environment since the velocity of cash in rural settings is much less than in urban settings. What implications does this have for development in human terms? Given the fact that remittances have been the lifeblood of many communities in Zimbabwe under severe economic strain, the limited financial contribution is suggestive of a community that is limited in terms of how it defines its own notion of development. Evidence of the limited scope lies in the conceptions of development as a statist, top-down process where mostly infrastructure and resources -largely defined in national terms- are availed to the community (see Table 3). Aspects such as personal growth or 'empowerment' were indeed popular but must be read within the context of the economic and political environment. In Zimbabwe, certain buzzwords have become so hackneyed that they lose meaning as analytic terms and even for conceptual purposes. This is not in and of itself problematic because empowerment has an expansive semantic range with meanings pouring into development from an enormous diversity of sources (Cornwall \& Brock, 2005, p.1046). However, in Zimbabwe and particularly in public discourse and as political rhetoric, it is often deployed to mean anything from provision of tools for self-improvement to distribution of farm inputs and implements. It is in such vague terms that empowerment was used by participants, not, as Rowlands (1995) would have it, understood as inclusive participation. Lastly, pensions also constituted to the lowly financial capital. The fact that pensions constitute a small percentage in the mix is hardly surprising given the history of uneven development based on racial lines in Zimbabwe as well as volatile labour market due to policy inconsistency (Chiripanhura \& Makwavarara, 2001).

The lowest contributing aspect in the portfolio was loans which were classified under social capital. The rationale here was that given the low inclusion in financial products, communities would be more inclined to participate in groupsavings or rely on friends and relatives for support. Social capital is suggestive of robust networks which can yield benefit to 
their members. The benefit need not necessarily be financial but for analytical convenience, has been presented as such. Loans from social groups and networks contribute a paltry figure. While the reasons for this were not interrogated in depth, conjecture would suggest that widespread limited resources curtail the ability of loans to be issued out from one household to another. In other words, in a community of poor people, there is hardly any surplus available for provision to other households as loans.

At the start of the paper, we observed the transition of development thinking over time and observed how these changes have morphed together with perspectives from fields such as cultural anthropology. In a world trying to 'catch up', caught in near-perpetual dependency, then globalized and glocalized, it is difficult to make sense of whose development it is anyway. However, through such contributions as Sen (1999)'s tome and more human-centred approaches, it is now possible to make sense of the human being at the heart of development. In Nkayi, this conceptual perspective has been employed to assess households participating in various activities. The activities are spread out over different economies which participants take part in. Such economies are not to be read as an economist would, but encompass moral, social and cultural economies. These have-for simplification- been analysed using livelihoods approaches to reveal the diversity of activity across such fields as mining, farming, finance, social relations and labour. Although such participation appears to be diverse, the depth or spread of diversity is however very narrow. Often, many households were absent from participating in one activity or another. Therefore, while many dimensions may exist, the ability of households to actively engage is much curtailed. What implications does this have for notions of development? It appears that participants in the study are still waiting for their version of development to materialise. They have largely not attained what they hoped for (see Table 5) and often lack sufficient currency to pool together enough capital in various economies. In Sen's words, their capabilities are diminished. This poses challenges for policymakers in Zimbabwe and prompts a rethink for development scholars in general to reassess how aspirations for development in a turbulent world even at local level can be achieved.

\section{Conclusions}

The study sought to place rural economies within the broad development agenda. While development theory has presented processes of development as constitutive of ideological contrasts manifest in dependency states, modernization programmes and globalization among others, development has been construed as a human endeavour. Such a perspective is largely influenced by Amartya Sen's insights where development is posited as a quest for freedom. What such freedom means to whom is a matter which varies from one context to another. Such has been the case in Nkayi where participants demonstrated a diverse engagement in various activities and economies. Such diversity reveals that agriculture is not the only source of sustenance although it undeniably is the most prominent. Instead, participants rely on a range of other economies which include mining, household labour and social networks. In using the term economies, the study did not concern itself with a purely economic sense of the term but situated it within a broader socio-economic sense. The conclusion from the study is that more inclusion is required for households to fully achieve their potential and for their visions of development to manifest. Although there are a range of economies which can be readily identified, often, few households participate in each of these economies and thus broadening is desperately required. A final word would be to suggest areas for further research which could add value to the diversity of economies and inclusion in the economies. A more extensive study is required which captures a wider sample. As stated earlier, the study sample omitted wards -such as Ward 29- which could have offered more insights into economy options. In addition, different methodologies could be deployed to analyse similar issues from as many perspectives as possible.

\section{References}

i. Appadurai, A. (1990). Disjuncture and Difference in the Global Cultural Economy. Theory, Culture \& Society , 7, 295310, doi: 10.1177/ 026327690007002017.

ii. Baudron, F., Andersson, J. A., Corbeels, M., \& Giller, K. E. (2012). Failing to Yield? Ploughs, Conservation Agriculture and the Problem of Agricultural Intensification: An Example from the Zambezi Valley, Zimbabwe. Journal of Development Studies, 393-412.

iii. Brundtland Commission. (1987). Report of the World Commission on Environment and Development: Our Common Future. Retrieved 2017, from http:/ / habitat.igc.org/ open-gates/ ocf

iv. Bryceson, D. F., Jønsson, J. B., \& Verbrugge, H. (2013). Prostitution or partnership? Wifestyles in Tanzanian artisanal gold-mining settlements. The Journal of Modern African Studies, 51 (1), 33 - 56, doiI: 10.1017/ S0022278X12000547.

v. Buescher, M., Halbrendt, C., \& Sullivan, P. Z. (1999, May). Community-Business Matching: a New Model for Rural Economic Development. Retrieved December 12, 2017, from http:/ / www.ageconsearch.umn.edu/ bitsstream/ 21696/ 1/ sp99bu01.pdf

vi. Chambers, R., \& Conway, R. (1992). Sustainable Rural Livelihoods: Practical Concepts for the 21st Century [IDS Discussion Paper, 296]. 1-29. University of Sussex: Institute of Development Studies.

vii. Chiripanhura, B. M., \& Makwavarara, T. (2001). The labour market and economic development 1980-2000. Harare: Zimbabwe Congress of Trade Unions.

viii. Cornwall, A., \& Brock, K. (2005). What Do Buzzwords Do for Development Policy? A Critical Look at 'Participation', 'Empowerment' and 'Poverty Reduction'. Third World Quarterly, 26 (7), 1043-1060. 
ix. Crush, J., \& Tevera, D. (2010). Exiting Zimbabwe. In J. Crush, \& D. Tevera (Eds.), Zimbabwe's Exodus: Crisis, Migration, Survival (pp. 1-49). Cape Town \& Ottawa: SAMP \& IDRC.

x. Ellis, F., \& Freeman, H. A. (2005). Rural Livelihoods and Poverty Reduction Policies. London: Routledge.

xi. Genesis Analytics. (2003). Access to Financial Services in Swaziland - FinMark Trust Research Paper No. 4. Johannesburg: FinMark Trust.

xii. Gumbo, D., Snelder, D., Wuta, M., \& Nyagumbo, I. (2012). Zimbabwe: Keeping Runoff on the Land. In W. Critchley, \& J. Gowing, Water Harvesting in Sub-Saharan Africa (pp. 147-168). Abingdon: Routledge.

xiii. Hoko, Z. (2005). An assessment of the water quality of drinking water in rural districts in Zimbabwe. The case of Gokwe South, Nkayi, Lupane, and Mwenezi districts. Physics and Chemistry of the Earth , 30, 859-866 doi:10.1016/j.pce.2005.08.031.

xiv. Jones, J. L. (2010). 'Nothing is Straight in Zimbabwe': The Rise of the Kukiya-kiya Economy 2000-2008 . Journal of Southern African Studies, 36 (2), 285-299. doi:10.1080/ 03057070.2010.485784.

xv. Kerzner, S. (2009). Cash and Carry": Understanding the Johannesburg- Zimbabwe remittance Corridor. Discussion Document prepared for the FinMark Trust. Johannesburg: FinMark Trust.

xvi. Mabhena, C. (2012). Mining with a Vuvuzela: Reconfiguring Artisanal mining in Southern Zimbabwe and its Implications to Rural Livelihoods. Journal of Contemporary, 219-233.

xvii. Marongwe, L. S., Kwazira, K., Jenrich, M., Thierfelder, C., Kassam, A., \& Friedrich, T. (2011). An African success: the case of conservation agriculture in Zimbabwe. International Journal of Agricultural Sustainability , 153-161.

xviii. Nkayi RDC. (2014). Good harvest eyed...as local farmers adopt conservation agriculture. Masakhe Issue 003/15 . Nkayi: Nkayi RDC.

xix. NkayiRDC. (n.d.). Nkayi Rural District Council. Retrieved July 04, 2017, from http:/ / nkayirdc.co.zw/ index.php/ aboutus/ nkayi-rural-district-council.html

xx. Nyamunda, T., \& Mukwambo, P. (2012). The State and the Bloody Diamond Rush in Chiadzwa: Unpacking the Contesting Interests in the Development of Illicit Mining and Trading, c.2006-2009. Journal of Southern African Studies, 145-166.

xxi. Peet, R., \& Hartwick, E. (2009). Theories of Development: Contentions, Arguments, Alternatives. New York: The Guilford Press.

xxii. Rowlands, J. (1995). Empowerment Examined. Development in Practice, 5 (2), 101-107.

xxiii. Sen, A. (1999). Development as Freedom. New York: Alfred K. Knopf.

xxiv. Tevera, D., \& Crush, J. (2010). Discontent and Departure: Attitudes of Skilled Zimbabweans Towards Emigration. In J. Crush, \& D. Tevera (Eds.), Zimbabwe's Exodus: Crisis, Migration, Survival (pp. 112-130). Cape Town \& Ottawa: SAMP $\&$ IDRC.

xxv. Todaro, M. P. (1982). Economics for a Developing World (2nd ed.). London \& New York: Longman.

xxvi. UNDP. (2010). the Real Wealth of Nations: Pathways to Human Development [Human Development Report 2010 25th Anniversary Edition]. New York: United Nations Development Programme.

xxvii. Wekwete, K. H. (1988). Rural Growth Points in Zimbabwe - prospects for the future. Journal of Social Development in Africa, 3 (2), 5-16.

xxviii. ZimStat. (2011). Census 2012: Preliminary Report. Harare: Zimbabwe National Statistics Agency.

xxix. ZIMVAC. (2016). Zimbabwe Vulnerability Assessment Committee (ZimVac) 2016 Rural Livelihoods Assessment. Harare: Food and Nutrition Council.

\section{Appendix}

\begin{tabular}{|c|c|c|c|c|c|}
\hline \multicolumn{9}{|c|}{ Mining } \\
\hline \multirow{3}{*}{ Valid } & 0 & 28 & 82.4 & Valid Percent & Cumulative Percent \\
\cline { 2 - 6 } & 50 & 1 & 2.9 & 82.4 & 82.4 \\
\cline { 2 - 6 } & 60 & 2 & 5.9 & 2.9 & 85.3 \\
\cline { 2 - 6 } & 80 & 1 & 2.9 & 5.9 & 91.2 \\
\cline { 2 - 6 } & 120 & 1 & 2.9 & 2.9 & 94.1 \\
\cline { 2 - 6 } & 150 & 1 & 2.9 & 2.9 & 97.1 \\
\cline { 2 - 6 } & Total & 34 & 100.0 & 100.0 & 100.0 \\
\hline
\end{tabular}

Table 8 


\begin{tabular}{|c|c|c|c|c|c|}
\hline \multicolumn{7}{|c|}{ Farming } \\
\hline \multirow{3}{*}{ Valid } & .00 & Frequency & Percent & Valid Percent & Cumulative Percent \\
\cline { 2 - 6 } & 10.00 & 2 & 5.9 & 5.9 & 5.9 \\
\cline { 2 - 6 } & 20.00 & 1 & 2.9 & 2.9 & 8.8 \\
\cline { 2 - 6 } & 30.00 & 3 & 8.8 & 8.8 & 17.6 \\
\cline { 2 - 6 } & 50.00 & 1 & 2.9 & 2.9 & 20.6 \\
\cline { 2 - 6 } & 60.00 & 8 & 20.6 & 20.6 & 61.2 \\
\cline { 2 - 6 } & 70.00 & 6 & 17.6 & 23.5 & 82.7 \\
\cline { 2 - 6 } & 80.00 & 2 & 5.9 & 17.6 & 88.2 \\
\cline { 2 - 6 } & 90.00 & 1 & 2.9 & 2.9 & 91.2 \\
\cline { 2 - 6 } & 100.00 & 3 & 8.8 & 8.8 & 100.0 \\
\cline { 2 - 6 } & Total & 34 & 100.0 & 100.0 & \\
\hline
\end{tabular}

Table 9

\begin{tabular}{|c|c|c|c|c|l|}
\hline \multicolumn{9}{|c|}{ Pensions } \\
\hline \multirow{3}{*}{ Valid } & .00 & Frequency & Percent & Valid Percent & Cumulative Percent \\
\cline { 2 - 6 } & 50.00 & 31 & 91.2 & 91.2 & 91.2 \\
\cline { 2 - 6 } & 70.00 & 2 & 5.9 & 5.9 & 97.1 \\
\cline { 2 - 6 } & Total & 1 & 2.9 & 2.9 & 100.0 \\
\hline
\end{tabular}

Table 10

\begin{tabular}{|c|c|c|c|c|c|}
\hline \multicolumn{6}{|c|}{ Loans } \\
\hline \multirow{3}{*}{ Valid } & .00 & Frequency & Percent & Valid Percent & Cumulative Percent \\
\cline { 2 - 6 } & 10.00 & 29 & 85.3 & 85.3 & 85.3 \\
\cline { 2 - 6 } & 20.00 & 1 & 2.9 & 2.9 & 88.2 \\
\cline { 2 - 6 } & Total & 34 & 11.8 & 11.8 & 100.0 \\
\hline
\end{tabular}

Table 11

\begin{tabular}{|c|c|c|c|c|c|}
\hline \multicolumn{7}{|c|}{ Assets } \\
\hline \multirow{3}{*}{ Valid } & .00 & Frequency & Percent & Valid Percent & Cumulative Percent \\
\cline { 2 - 6 } & 10.00 & 4 & 50.0 & 50.0 & 50.0 \\
\cline { 2 - 6 } & 20.00 & 5 & 11.8 & 11.8 & 61.8 \\
\cline { 2 - 6 } & 30.00 & 2 & 5.9 & 14.7 & 76.5 \\
\cline { 2 - 6 } & 40.00 & 2 & 5.9 & 5.9 & 82.4 \\
\cline { 2 - 6 } & 50.00 & 3 & 8.8 & 8.9 & 88.2 \\
\cline { 2 - 6 } & 100.00 & 1 & 2.9 & 2.9 & 97.1 \\
\cline { 2 - 6 } & Total & 34 & 100.0 & 100.0 & 100.0 \\
\hline
\end{tabular}

Table 12

\begin{tabular}{|c|c|c|c|c|c|}
\hline \multicolumn{6}{|c|}{ Labour } \\
\hline & & Frequency & Percent & Valid Percent & Cumulative Percent \\
\hline \multirow[t]{7}{*}{ Valid } & 10.00 & 2 & 5.9 & 5.9 & 5.9 \\
\hline & 20.00 & 12 & 35.3 & 35.3 & 41.2 \\
\hline & 30.00 & 9 & 26.5 & 26.5 & 67.6 \\
\hline & 40.00 & 5 & 14.7 & 14.7 & 82.4 \\
\hline & 50.00 & 5 & 14.7 & 14.7 & 97.1 \\
\hline & 60.00 & 1 & 2.9 & 2.9 & 100.0 \\
\hline & Total & 34 & 100.0 & 100.0 & \\
\hline
\end{tabular}

Table 13 